\title{
Anvendelse af fæerdselslovgivning ud over landets grænser
}

\author{
Af landsdommer BJARNE FRANDSEN, Viborg.
}

I dette tidsskrift 1960 , p. $346-7$ har statsadvokat Karl Lous rejst spørgsmålet, om motorvognloven under en straffesag i Norge kan anvendes ved kørsel udenfor Norge. Anledningen er en bilulykke forvoldt af en nordmand med en norsk bil i Danmark. Der var i den omtalte sag enighed om, at den norske straffelovs bestemmelse om uagtsomt manddrab kunne være anvendt. Lagmannsretten antog, at bestemmelsen i motorvognlovens $\S 171$. ledd. $\mathrm{nr} .2 \mathrm{om}$ agtpågivenhed som svarer til den danske færdselslovs $\S 24$ stk. 1 - måtte kunne anvendes på den omhandlede k $\phi r s e l$, hvorefter der skete domsfældelse for overtrædelse heraf (frifindelse for tiltale efter straffeloven). Der var endvidere enighed om, at de norske trafikregler ikke kunne anvendes ved k $\phi$ rsel i udlandet, og tiltale var derfor ikke rejst for overtrædelse af disse regler. Statsadvokaten oplyser, at der er sket enkelte domfæeldelser for spiritusk $\phi$ rsel i udlandet, men antager at der i $\phi$ vrigt kan rejses tvivl om i hvilken udstrakning andre bestemmelser $\mathrm{i}$ motorvognloven kan anvendes udenfor landets grænser. Der henvises dernæst til, at der med den $\phi$ gede trafik over landegrænsen er grund til at frygte, at spørgsmålet snart kan blive aktuelt igen, idet det må erkendes, at det ikke altid er muligt at få sådanne sager afgjort i ulykkeslandet - hvilket ville være mest $\phi$ nskeligt.

Det er klart, at sp $\phi$ rgsmålet må blive aktuelt med den voldsomt øgede motorsamfærdsel imellem alle de europæiske lande. Det er da også allerede optaget til forhandling med henblik på afslutning af en europæisk konvention om behandling af trafikforseelser. Forhandlingerne er imidlertid på et så foreløbigt stade, at der ikke kan offentligg $\phi$ res noget nærmere herom.

Også de danske domstole har dog allerede måttet tage stilling til færdselsforseelser begået af danske i udlandet ligesom til trafikforseelser begået af udlændinge i Danmark, jfr. min Håndbog i Færdselslovgivningen p. 27-28. Det er her antaget, at den danske færdselslov vil kunne anvendes ved k $\phi$ rsel i udlandet, når der ikke er relevante forskelligheder mellem udlandets og de danske regler. Det er en forudsatning, at der kun rejses tiltale ved grovere overtrædelser, men de egentlige færdselsforskrifter undtages ikke. For såvidt angår frakendelse af førerret er det udtrykkeligt hjemlet i færdselslovens $\S 70$, stk. 8, at der kan ske frakendelse af førerretten under en straffesag her i landet, når en person, der har dansk indf $\phi$ dsret eller er bosat i den danske stat, i fremmed stat er straffet for et forhold, der bed $\varnothing \mathrm{mt}$ efter 
den danske færdselslov ville have medf $\varnothing \mathrm{rt}$ frakendelse af førerretten. Med hensyn til straf findes derimod ingen bestemmelser i færdselsloven, men i straffelovens $\$ 7 \mathrm{nr}$. 2 en bestemmelse om, at sådanne handlinger hører under dansk straffemyndighed, hvis de er strafbare også efter den i udlandet gældende lovgivning. Denne bestemmelse må sammenholdes med straffelovens $\S 10$, hvorefter bed $\varnothing \mathrm{mm}$ elsen skal ske efter dansk lovgivning, dog ikke med strengere straf end hjemlet ved gerningslandets lovgivning. Den svenske S. L. kap. 1 indeholder nogenlunde tilsvarende regler, $\operatorname{dog}$ at der kræves påtalebegæring af kongen, såfremt forseelsen ikke er rettet mod svensk mann eller svensk interesse.

Såvel herefter som efter almindelige retsprincipper turde det således være en forudsætning for anvendelsen af dansk (nordisk) færdselslov på trafikforseelser udenfor landets grænser, at forseelsen er strafbar såvel efter gerningslandets som efter bopælslandets lovgivning. Medens nu bed $\varnothing$ mmelsen af fæerdselsforseelser begået i udlandet vel bør ske efter bopælslandets - det retsanvendende lands - lovgivning, b $\phi r$ selve de færdselsregler, som skal anvendes, principielt være gerningslandets - f. eks. med hensyn til højre eller venstre $\mathrm{k} \phi \mathrm{rsel}$, vigepligt o. s. v.. Med en sådan dobbelt garanti kan ingen tiltalt beklage sig over færdselsreglernes anvendelse udenfor landets eget territorium, det vil tværtimod kunne være en fordel at få afgørelsen i bopæelslandet fremfor i gerningslandet, jfr. Stephan Hurwitz: Den danske kriminalret, alm. del 151. Hvortil kommer, at behandlingen så ikke behøver ske i hastværk, evt. med afbrydelse af en rejseplan. For de retsanvendende myndigheder vil sảdanne regler selvsagt også medføre fordele. Da der vil kunne opstå afgrænsningsvanskeligheder, og der også er fuldbyrdelsesvanskeligheder ved forseelser begået af danske i udlandet og pådømt der, må det såvel af hensyn til retsanvendelsen som til retsbryderne håbes, at det ikke vil vare alt for længe, f $\phi$ r der opnås en konvention for et større eller mindre antal lande.

Det må dog erindres, at der med hensyn til det i færdselssager meget vigtige spørgsmål, erstatningsansvaret, ikke vil kunne anvendes en national færdselslov udenfor landets grænser jfr. min håndbog 1 . c.. Jfr. UfR $1954-772(\mathrm{H})$. Antaget at den dagældende motorlovs bestemmelse om panteret i biler ikke kunne anvendes overfor en dansk bil, som havde forvoldt skade i Belgien.

Bjarne Frandsen. 